\title{
Effect of Probiotic Administration on the Immune Response: A Systematic Review of Experimental Models in Rats
}

\author{
Viviam de Oliveira Silva ${ }^{1 *}$, Renata de Carvalho Foureaux ${ }^{1}$, Thiago Santos Araujo ${ }^{1}$, Ana \\ Paula Peconick ${ }^{2}$, Marcio Gilberto Zangeronimo ${ }^{1}$ and Luciano José Pereira ${ }^{1}$ \\ ${ }^{I}$ Departamento de Medicina Veterinária; Setor de Fisiologia e Farmacologia; Universidade Federal de Lavras; \\ Lavras - MG - Brasil. ${ }^{2}$ Departamento de Medicina Veterinária; Setor de Medicina Veterinária Preventiva; \\ Universidade Federal de Lavras; Campus Universitário, C.P.: 3037; 37200-000; Lavras - MG - Brasil
}

\begin{abstract}
The probiotic influence on the immune system, especially under pathogenic challenge conditions, still remains controversial. To address this, a systematic review of current studies concerning the efficacy of probiotics on the immune response of rats subjected to experimental challenges was conducted. The survey was conducted using PubMed, ISI Web of Science and Scielo databases. Only studies which tested probiotics in vivo in rats were included. The experimental design, methodological quality, and results of the articles were analyzed. In total 21 articles were selected for this study. The most commonly used microorganisms in the experiments were those of the genus Lactobacillus, which was reported in 12 articles. The second most often used genus was Bifidobacterium (B. animalis and B.longum). In general, the probiotics use against experimental pathogenic challenges was successful: $86 \%$ of the selected articles reported a beneficial effect on the immune response associated with the use of probiotics.
\end{abstract}

Key words: immunity, probiotics, rats, dietary supplements

\section{INTRODUCTION}

It is well known that the nutrition, through a series of complex interactions, is able to improve the health status of the animals. In animal production, several substances have been used as growth promoters, including probiotics, which are live microorganisms that improve the microbial balance in the gastrointestinal tract, thereby increasing the efficiency with which the nutrients are used. In other areas, probiotics have been used for preventive purposes, to inhibit the proliferation of microorganisms that cause gastrointestinal disturbances (Chaucheyras-Durand et al. 2008; Vanderpool et al. 2008; Mountzouris et al. 2009;
Chaucheyras-Durand and Durant 2010; Maragkoudakis et al. 2010).

By definition, probiotics are microorganisms that are regulated as dietary supplements, when ingested in sufficient quantities, have beneficial effects on the health of the host (FAO 2002; Budiño et al. 2005; Siró et al. 2008; Tsubura et al. 2009). Most probiotics contain bacteria of the genus Lactobacillus and Bifidobacterium (Brizuela et al. 2001; Peran et al. 2006; Zeng et al. 2009; Bloise et al. 2010; de Roock et al. 2010). However, certain bacteria of the genus Enterococcus (Maragkoudakis et al. 2010), Leuconostoc and Streptococcus (Zanini et al. 2007) and yeasts, such as Saccharomyces cerevisiae and Saccharomyces boulardii (Baptista

*Author for correspondence: vivian_osbio@yahoo.com.br 
et al. 2005; Generoso et al. 2010) can be considered to be probiotic microorganisms.

Numerous studies have demonstrated the effectiveness of these microorganisms at improving the intestinal health of the animals and, thereby, their metabolic and physiological status Brizuela et al. 2001). Besides the direct effect of probiotics on the adherence of pathogenic bacteria in the intestinal epithelium, several studies have also correlated probiotic administration with the positive effects on the immune response in animals (Borchers et al. 2009; Amit-Romach et al. 2010; Generoso et al. 2010; Fink 2010) and humans (Nomoto 2005; Salminen et al. 2005; Lomax and Calder 2009). Other benefits identified in in vitro studies include significant inhibition of infection by L. monocytogenes (Corr et al. 2007); strong induction of IL-12 and TNF- $\alpha$ in monocytes and cultured human peripheral blood mononuclear cells (PBMC) (Fink 2010); and inhibition of the growth of C. albicans (Verdenelli et al. 2009), among others. However, no consensus exists in the literature on the preventive or therapeutic use of probiotics to improve the immune system's ability to defend against different infectious agents.

Animal models, such as rats, are often used to simulate the physiological and pathological mechanisms in vivo. Results are then extrapolated to other species, which cannot be directly investigated, due to ethical, financial and/or facilities management issues, or simply because of a lack of physical space (Fagundes and Taha 2004; DaMatta 2010). Thus, detailed studies on a single species are necessary for comparative analysis. Therefore, the objective of the present study was to conduct a systematic review of the efficacy of probiotics on the immune response in rats.

\section{MATERIALS AND METHODS}

\section{Research strategy}

An electronic search of the PubMed database (http://www.ncbi.nlm.nih.gov) was conducted in October 2010, using the following keywords: immunity, probiotics, rats. To confirm the findings and obtain supplementary studies, a similar strategy was employed for the ISI Web of Science database (http://apps.isiknowledge.com) and Scielo database (http://www.scielo.org/php/index.php), using the same keywords (also in Portuguese and Spanish, when applicable).

\section{Study Selection}

For the present review, only in vivo studies using probiotics and rats were selected. Studies conducted on mice, rabbits, guinea pigs, or other types of animal models were excluded.

No restrictions were made for the type of probiotic used in the study, administration form, or administration period against an experimental challenge (for prevention and treatment). Additionally, no date, lunguage or number of animals were restricted as selection criteria.

\section{Data extraction and Quality criteria}

Two researchers conducted article searches separately, and independently verified the compliance of the selected papers with the inclusion criteria. In the cases of divergence between the papers, all the criteria were reviewed and discussed. Table 1 displays the data related to the experimental design of the retrieved articles.

After study selection, quality analysis was conducted and scores were assigned to specific scientific criteria as described in Table 2. Selection criteria were defined to evaluate both the protective effects of probiotics in relation to the immune system and the methodological quality of the selected articles.

However, not all the parameters used were scored on the quality scale (such as animal strain, type of microorganism used and evaluated technique, among others), but were taken into consideration as they were relevant to the subsequent discussion. The scientific criteria used were adapted from other systematic reviews (Noli and Auxilia 2005; Negre et al. 2009; Pereira et al. 2010). The parameters were classified as either adequate (score: 2) or unclear/partially adequate (score: 1). The following parameters were scored:

- Sample number: Studies with sample groups containing $\geq 6$ animals received a score of 2 and studies with less than 6 animals per group received a score of 1 .

- Randomization: Studies reporting nonrandomized experiments or studies for which the degree of randomization was not clearly described in the text received a score of 1 , while studies using randomized experimental designs received a score of 2 .

- Control group: Studies that included a control group received a score of 2 , while studies that did not include a control group or did not 
clearly mention a control group in the text received a score of 1 .

- Blind evaluation: Studies which included blind assessments in their experimental design received a score of 2 , while studies whose experimental designs did not include blind assessments, or for which blind assessments were not clearly reported in the text received a score of 1.

- Interference factors: Studies that did not evaluate interference factors received a score of 1, while studies which considered additional factors, such as stress, hormonal evaluation, and variations between the males and females received a score of 2 .

- Pathogenic challenge: Studies which did not include an experimental challenge received a score of 1 , while studies which subjected the animals to an experimental challenge received a score of 2 .

The maximum total score was 12 points.

Table 1 - Summary of the Selected Studies.

\begin{tabular}{|c|c|c|c|c|c|c|c|c|c|c|c|c|}
\hline 1 & 2 & 3 & 4 & 5 & 6 & 7 & 8 & 9 & 10 & 11 & 12 & 13 \\
\hline $\mathrm{A}$ & Wistar & $\begin{array}{l}\text { Lactobacillus } \\
\text { helveticus and } \\
\text { Streptococcus } \\
\text { thermophilus } 10^{6} \\
\text { CFU }\end{array}$ & $\mathrm{Y}$ & $\begin{array}{l}\text { Pre- } \\
\text { and post- } \\
\text { operative } \\
\text { period }\end{array}$ & 30 & $\mathrm{Y}$ & $\mathrm{U}$ & $\mathrm{Y}$ & $\mathrm{U}$ & $\begin{array}{l}\text { Laparotomy } \\
\text { with colon } \\
\text { anastomosis }\end{array}$ & $\begin{array}{l}\text { Intestine } \\
\text { (colon) }\end{array}$ & $\begin{array}{l}\text { Evaluation of the IGA, total } \\
\text { protein, albumin and globulin; } \\
\text { analysis of DNA content by the } \\
\text { method Gyles and Meyers. }\end{array}$ \\
\hline B & Wistar & $\begin{array}{l}\text { Streptococcus } \\
\text { thermophilus, } \\
\text { Lactobacillus } \\
\text { acidophilus and } \\
\text { Bifidobacterium } \\
\text { lactis } 10^{9} \mathrm{CFU}\end{array}$ & $\mathrm{Y}$ & $\begin{array}{l}\text { Before the } \\
\text { challenge } \\
\text { and } \\
\text { throughout } \\
\text { the } \\
\text { experiment }\end{array}$ & 6 & $\mathrm{Y}$ & $\mathrm{U}$ & $\mathrm{Y}$ & $\mathrm{N}$ & $\begin{array}{l}\text { Induction } \\
\text { of colitis }\end{array}$ & $\begin{array}{l}\text { Intestine } \\
\text { (colon and } \\
\text { lower end of } \\
\text { the ileum) }\end{array}$ & $\begin{array}{l}\text { Evaluation of colonized tissues } \\
\text { by real-time PCR. Morphology } \\
\text { of the colon and damaged } \\
\text { tissue were histologically } \\
\text { evaluated. }\end{array}$ \\
\hline C & $\begin{array}{l}\text { Lewis, } \\
\text { Wistar } \\
\text { and } \\
\text { Balb/c }\end{array}$ & $\begin{array}{l}\text { Lactobacillus casei } \\
10^{9} \mathrm{CFU}\end{array}$ & $\mathrm{N}$ & $\begin{array}{l}\text { Before the } \\
\text { challenge } \\
\text { and } \\
\text { throughout } \\
\text { the } \\
\text { experiment }\end{array}$ & 16 & Y & $\mathrm{U}$ & Y & $\mathrm{U}$ & EAE induction & $\begin{array}{l}\text { Ears } \\
\text { (epidermis) or } \\
\text { central } \\
\text { nervous } \\
\text { system }\end{array}$ & $\begin{array}{l}\text { Isolation and proliferation of } \\
\text { lymph nodes, IL- } 4 \text { and IFN- } \gamma \\
\text { by ELISA, cytokine through } \\
\text { standard curves of recombinant } \\
\text { IL-4 or IFN- } \gamma \text {, analysis of gene } \\
\text { expression in liver and thymus } \\
\text { tissue, as well as frozen MLN; } \\
\text { analysis of the amount of RNA } \\
\text { by spectrophotometry and } \\
\text { RNA integrity by gel } \\
\text { electrophoresis; microarray } \\
\text { analysis }\end{array}$ \\
\hline $\mathrm{D}$ & $\begin{array}{l}\text { Wistar } \\
\text { and } \\
\text { Lewis }\end{array}$ & $\begin{array}{l}\text { Lactobacillus } \\
\text { kefiranofaciens } 6 \mathrm{x} \\
10^{11} \mathrm{CFU}\end{array}$ & $\mathrm{N}$ & $\begin{array}{l}\text { Throughou } \\
\mathrm{t} \text { the } \\
\text { experiment }\end{array}$ & 5 & $\mathrm{~N}$ & $\mathrm{U}$ & $\mathrm{Y}$ & $\mathrm{Y}$ & $\mathrm{N}$ & - & ELISA and blood cell count \\
\hline $\mathrm{E}$ & $\begin{array}{l}\text { Sprague } \\
\text { Dawley }\end{array}$ & $\begin{array}{l}\text { Lactobacillus sp. } \\
10^{9} \mathrm{CFU}\end{array}$ & $\mathrm{U}$ & $\begin{array}{l}\text { Before the } \\
\text { challenge } \\
\text { and } 9,3 \\
\text { and } 10 \\
\text { days after } \\
\text { challenge }\end{array}$ & 3 & $\mathrm{Y}$ & $\mathrm{U}$ & $\mathrm{Y}$ & $\mathrm{N}$ & $\begin{array}{l}\text { Cecum } \\
\text { perforation for } \\
\text { polymicrobial } \\
\text { infection }\end{array}$ & Cecum & $\begin{array}{l}\text { Intestine histology; counting } \\
\text { bacterial colonies; Backlight } \\
\text { analysis; serum TNF analysis } \\
\text { by ELISA. }\end{array}$ \\
\hline $\mathrm{F}$ & Wistar & $\begin{array}{l}\text { Lactobacillus casei } \\
2 \times 10^{9} \mathrm{CFU} .\end{array}$ & $\mathrm{U}$ & $\begin{array}{l}\text { Before and } \\
\text { after the } \\
\text { challenge }\end{array}$ & 6 & $\mathrm{Y}$ & $\mathrm{U}$ & $\mathrm{Y}$ & $\mathrm{N}$ & $\begin{array}{l}\text { Listeria } \\
\text { monocytogenes } \\
\text { (sensitization } \\
\text { caused by oral } \\
\text { infection) }\end{array}$ & $\begin{array}{l}\text { Gastro- } \\
\text { intestinal tract } \\
\text { and visceral } \\
\text { organs }\end{array}$ & $\begin{array}{l}\text { Bacteriological analysis; liver } \\
\text { and spleen histological } \\
\text { analysis; ALT levels and } \\
\text { concentration of total serum } \\
\text { bile acids by a Beckman } \\
\text { Synchron CX7, cell-mediated } \\
\text { immunity measured using the } \\
\text { DTH assay }\end{array}$ \\
\hline G & Wistar & $\begin{array}{l}\text { Lactobacillus } 2 \times 10^{9} \\
\text { CFU }\end{array}$ & $\mathrm{N}$ & $\begin{array}{l}\text { After the } \\
\text { challenge }\end{array}$ & 4 & $\mathrm{Y}$ & $\mathrm{U}$ & $\mathrm{Y}$ & $\mathrm{U}$ & $\begin{array}{l}\text { Listeria } \\
\text { monocytogenes } \\
\text { infection. }\end{array}$ & $\begin{array}{l}\text { Spleen and } \\
\text { liver }\end{array}$ & $\begin{array}{l}\text { Liver and } \quad \text { spleen } \\
\text { bacteriological analysis and } \\
\text { measurement } \text { of } L . \\
\text { monocytogenes }\end{array}$ \\
\hline $\mathrm{H}$ & $\begin{array}{l}\text { Sprague } \\
\text { Dawley }\end{array}$ & $\begin{array}{l}\text { Bifidobacterium } \\
\text { longum } 1 \times 10^{10} \mathrm{CFU}\end{array}$ & $\mathrm{N}$ & $\begin{array}{l}\text { From birth } \\
\text { until the } \\
\text { end of the } \\
\text { experiment }\end{array}$ & 10 & $\mathrm{U}$ & $\mathrm{U}$ & $\mathrm{Y}$ & $\mathrm{U}$ & $\mathrm{N}$ & - & $\begin{array}{l}\text { RNA concentration by } \\
\text { spectrophotometry, reverse } \\
\text { transcription, } \\
\text { cytokine and immunoglobulin } \\
\text { (by ELISA) }\end{array}$ \\
\hline
\end{tabular}


(Cont. Table 1)

\begin{tabular}{|c|c|c|c|c|c|c|c|c|c|c|c|c|}
\hline 1 & 2 & 3 & 4 & 5 & 6 & 7 & 8 & 9 & 10 & 11 & 12 & 13 \\
\hline I & $\begin{array}{l}\text { Lewis } \\
\text { and } \\
\text { Balb/c }\end{array}$ & $\begin{array}{l}\text { Lactobacillus casei } \\
2-4 \times 10^{8} \mathrm{CFU} \text { or } 1- \\
2 \times 10^{9} \mathrm{CFU}\end{array}$ & $\mathrm{N}$ & $\begin{array}{l}\text { Before the } \\
\text { challenge } \\
\text { and } \\
\text { throughout } \\
\text { the } \\
\text { experiment }\end{array}$ & 8 & $\mathrm{Y}$ & $\mathrm{U}$ & $\mathrm{Y}$ & $\mathrm{Y}$ & $\begin{array}{l}\text { Allergy } \\
\text { Induction }\end{array}$ & $\begin{array}{l}\text { Lymphocytes } \\
\text { in the lungs } \\
\text { and } \\
\text { ovalbumin- } \\
\text { specific } \\
\text { cytokines in } \\
\text { the spleen }\end{array}$ & $\begin{array}{l}\text { Specific ovalbumin IgE and } \\
\text { IgG1 titres in sera were } \\
\text { determined by ELISA. Th1 and } \\
\text { Th2 cytokines were measured } \\
\text { in the supernatants of spleen } \\
\text { cells that were cultured with } \\
\text { ovalbumin; IL-4, IL-5, IL-10, } \\
\text { IL-13 and IFN- } \gamma \text { analysis. }\end{array}$ \\
\hline $\mathrm{J}$ & $\begin{array}{l}\text { Lewis } \\
\text { and } \\
\text { Balb/c }\end{array}$ & $\begin{array}{l}\text { Bifidobacterium } \\
\text { animalis } 1 \times 10^{9} \mathrm{CFU}\end{array}$ & $\mathrm{N}$ & $\begin{array}{l}\text { Before the } \\
\text { challenge } \\
\text { and } \\
\text { throughout } \\
\text { the } \\
\text { experiment }\end{array}$ & 16 & $\mathrm{Y}$ & $\mathrm{U}$ & Y & $\mathrm{Y}$ & $\begin{array}{l}\text { OVA } \\
\text { (respiratory } \\
\text { allergy) or } \\
\text { EAE }\end{array}$ & $\begin{array}{l}\text { Lung or } \\
\text { central } \\
\text { nervous } \\
\text { system }\end{array}$ & $\begin{array}{l}\text { OVA-specific antibodies; } \\
\text { Cytokine; IgE ova-specific (by } \\
\text { ELISA) }\end{array}$ \\
\hline $\mathrm{K}$ & $\begin{array}{l}\text { Albino } \\
\text { rats }\end{array}$ & $\begin{array}{l}\text { Lactobacillus sp. } \\
10^{8} \mathrm{CFU}\end{array}$ & $\mathrm{N}$ & $\begin{array}{l}\text { Throughout } \\
\text { the } \\
\text { experiment }\end{array}$ & 6 & $\mathrm{Y}$ & $\mathrm{U}$ & $\mathrm{Y}$ & $\mathrm{Y}$ & $\begin{array}{l}\text { Induction of } \\
\text { diarrhea } \\
\text { (castor oil } \\
\text { used as a } \\
\text { laxative) }\end{array}$ & $\begin{array}{l}\text { Gastro- } \\
\text { intestinal tract }\end{array}$ & $\begin{array}{l}\text { Protein levels were determined } \\
\text { by the method of Buiret; blood } \\
\text { cell count }\end{array}$ \\
\hline $\mathrm{L}$ & $\begin{array}{l}\text { Sprague } \\
\text { Dawley }\end{array}$ & $\begin{array}{l}\text { Lactobacillus casei, } \\
\text { Lactobacillus } \\
\text { bulgaricus, } \\
\text { Streptococus } \\
\text { thermophilus, } \\
\text { Lactobacillus } \\
\text { acidophilus, } \\
\text { Lactobacillus } \\
\text { plantarum and } \\
\text { Bifidobacterium } \\
\text { infantis } 2 \times 10^{7} \mathrm{CFU} \\
\text { or } 4 \times 10^{8} \mathrm{CFU}\end{array}$ & $\mathrm{Y}$ & $\begin{array}{l}\text { From the } \\
\text { second day } \\
\text { of the } \\
\text { experiment } \\
\text { until } \\
\text { sacrifice }\end{array}$ & 1 & $\mathrm{U}$ & $\mathrm{U}$ & $\mathrm{Y}$ & $\mathrm{U}$ & $\begin{array}{l}\text { Cryptosporidi } \\
\text { osis }\end{array}$ & $\begin{array}{l}\text { Small } \\
\text { intestine } \\
\text { (cecum) }\end{array}$ & $\begin{array}{l}\text { Estimated amount of parasites } \\
\text { in the mucosa of the cecum by } \\
\text { Ziehl-Neelsen staining and } C \text {. } \\
\text { parvum by real-time PCR, } \\
\text { histological analysis of the } \\
\text { cecum; IFN- } \gamma \text {, IL-10 and TNF- } \\
\alpha\end{array}$ \\
\hline M & $\mathrm{U}$ & $\begin{array}{l}\text { Lactobacillus casei } \\
5 \times 10^{10} \mathrm{CFU} \text { or } \\
1 \times 10^{11} \mathrm{CFU}\end{array}$ & $\mathrm{N}$ & $\begin{array}{l}\text { Before the } \\
\text { challenge } \\
\text { and } \\
\text { throughout } \\
\text { the } \\
\text { experiment }\end{array}$ & 10 & $\mathrm{Y}$ & $\mathrm{U}$ & $\mathrm{Y}$ & $\mathrm{N}$ & $\begin{array}{l}\text { Infection with } \\
\text { E. coli }\end{array}$ & $\mathrm{U}$ & $\begin{array}{l}\text { IgA (ELISA), cytotoxicity of } \\
\text { NK cells, macrophages, TNF- } \\
\alpha, \text { IL- } 6 \text { and IL-12 }\end{array}$ \\
\hline $\mathrm{O}$ & $\begin{array}{l}\text { Fisher } \\
\text { and } \\
\text { Balb/c }\end{array}$ & $\begin{array}{l}\text { Lactobacillus } \\
\text { paracasei } 5 \times 10^{8} \\
\text { CFU }\end{array}$ & $\mathrm{N}$ & $\begin{array}{l}\text { After the } \\
\text { challenge }\end{array}$ & 5 & $\mathrm{U}$ & $\mathrm{U}$ & $\mathrm{Y}$ & $\mathrm{N}$ & $\begin{array}{l}\text { Air bags } \\
\text { (injection of } \\
\text { sterile air) }\end{array}$ & $\begin{array}{l}\text { Back of the } \\
\text { animal }\end{array}$ & $\begin{array}{l}\text { PMN accumulation and } \\
\text { phagocytic activity of these } \\
\text { cells, IFN- } \gamma, \text { TNF- } \alpha \text { and IL-10 } \\
\text { (ELISA), histopathology; } \\
\text { immunohistochemistry }\end{array}$ \\
\hline $\mathrm{P}$ & Wistar & $\begin{array}{l}\text { Lactobacillus } \\
\text { brevis, } \\
\text { Lactobacillus } \\
\text { plantarum, } \\
\text { Streptococcus } \\
\text { faecalism and } \\
\text { Bifidobacte-rium } \\
\text { brevis } 6 \times 10^{8} \mathrm{CFU}\end{array}$ & $\mathrm{Y}$ & $\begin{array}{l}\text { For } 3 \text { days } \\
\text { before } \\
\text { sacrifice }\end{array}$ & 10 & $\mathrm{Y}$ & $\mathrm{U}$ & $\mathrm{Y}$ & $\mathrm{Y}$ & Indomethacin & $\begin{array}{l}\text { Gastro- } \\
\text { intestinal tract }\end{array}$ & $\begin{array}{l}\text { Percentage of damaged area } \\
\text { (macroscopically); Histology } \\
\text { of the gastric mucosa, ileum } \\
\text { and } \\
\text { immunohistochemistry colon, } \\
\text { lymphocytes B (CD 20) and T } \\
(\mathrm{CD} 4+\text { ) }\end{array}$ \\
\hline Q & $\mathrm{U}$ & $\begin{array}{l}\text { Lactobacillus } \\
\text { plantarum and } \\
\text { Lactobacillus } \\
\text { murines } \text { CFU (UC) }\end{array}$ & $\mathrm{N}$ & $\begin{array}{l}\text { During the } \\
\text { challenge }\end{array}$ & $\mathrm{U}$ & $\mathrm{U}$ & $\mathrm{U}$ & $\mathrm{Y}$ & $\mathrm{N}$ & EAE & $\begin{array}{l}\text { Central } \\
\text { nervous } \\
\text { system }\end{array}$ & Cytokines and DNA \\
\hline $\mathrm{R}$ & $\begin{array}{l}\text { Sprague } \\
\text { Dawley }\end{array}$ & $\begin{array}{l}\text { Lactobacillus } \\
\text { acidophilus, L.. } \\
\text { helveticus and } \\
\text { Bifidobacterium } \\
\text { CFU (UC) }\end{array}$ & $\mathrm{Y}$ & $\begin{array}{l}\text { Throughout } \\
\text { the } \\
\text { experiment }\end{array}$ & $\mathrm{U}$ & Y & $\mathrm{U}$ & $\mathrm{Y}$ & $\mathrm{U}$ & $\begin{array}{l}\text { Azinomethane } \\
\text { (colon } \\
\text { carcinoma) }\end{array}$ & Colon & $\begin{array}{l}\text { Analysis of the proliferation } \\
\text { rate of the mucosa, mesenteric } \\
\text { lymph nodes were removed } \\
\text { from rats for analysis of } \\
\text { intestinal immune system } \\
\text { markers, ACF determination; } \\
\text { tumor detection }\end{array}$ \\
\hline S & Wistar & $\begin{array}{l}\text { Lactobacillus } \\
\text { paracasei } 3 \times 10^{7} \\
\text { CFU }\end{array}$ & $\mathrm{N}$ & $\begin{array}{l}\text { During the } \\
\text { challenge }\end{array}$ & 7 & Y & $\mathrm{U}$ & $\mathrm{Y}$ & $\mathrm{U}$ & $\begin{array}{l}\text { Ischemia and } \\
\text { reperfusion }\end{array}$ & Liver & $\begin{array}{l}\text { Hepatic microcirculation, liver } \\
\text { histology, Western blotting } \\
\text { analysis, plasma assessment; } \\
\text { bacteriological evaluation in } \\
\text { the small intestine }\end{array}$ \\
\hline
\end{tabular}

(Cont. ...) 
(Cont. Table 1)

\begin{tabular}{|c|c|c|c|c|c|c|c|c|c|c|c|c|}
\hline 1 & 2 & 3 & 4 & 5 & 6 & 7 & 8 & 9 & 10 & 11 & 12 & 13 \\
\hline $\mathrm{T}$ & Fischer & $\begin{array}{l}\text { Lactobacillus } \\
\text { rhamnosus and } \\
\text { Bifidobacterium } \\
\text { lactis } 5 \times 10^{8} \mathrm{CFU} \text { or } \\
5.5 \times 10^{8} \mathrm{CFU}\end{array}$ & $\mathrm{Y}$ & $\mathrm{U}$ & 32 & $\mathrm{Y}$ & $\mathrm{U}$ & $\mathrm{Y}$ & $\mathrm{U}$ & $\begin{array}{l}\text { Azinomethane } \\
\text { (colon } \\
\text { carcinoma) }\end{array}$ & Colon & $\begin{array}{l}\text { Immunofluorescence of } \\
\text { lymphocyte subpopulations } \\
\text { through the spleen and MLN, } \\
\text { flow cytometry analysis; IL-10 } \\
\text { and IFN- } \gamma \text { by ELISA }\end{array}$ \\
\hline V & Lewis & $\begin{array}{l}\text { Lactobacillus casei } \\
2 \times 10^{10} \mathrm{CFU}\end{array}$ & $\mathrm{N}$ & $\begin{array}{l}\text { After } \\
\text { induction } \\
\text { and during } \\
\text { the whole } \\
\text { experiment }\end{array}$ & $\mathrm{U}$ & $\mathrm{Y}$ & $\mathrm{Y}$ & $\mathrm{Y}$ & $\mathrm{Y}$ & $\begin{array}{l}\text { Induction of } \\
\text { rheumatoid } \\
\text { arthritis } \\
\text { (collagen type } \\
\text { II) }\end{array}$ & Ankle (foot) & $\begin{array}{l}\text { Histopathological analysis of } \\
\text { the hind paws; cytokines by } \\
\text { RT-PCR, IgG (ELISA), TNF- } \\
\alpha \text {, IL-10 and Foxp3 by FACS } \\
\text { Calibur Flow Cytometer }\end{array}$ \\
\hline $\mathrm{X}$ & $\begin{array}{l}\text { Sprague } \\
\text { Dawley }\end{array}$ & $\begin{array}{l}\text { Lactobacillus } \\
\text { acidophilus } 2.5 \mathrm{x} \\
10^{8} \mathrm{CFU}\end{array}$ & $\mathrm{N}$ & $\begin{array}{l}\text { After the } \\
\text { challenge }\end{array}$ & 7 & $\mathrm{U}$ & $\mathrm{U}$ & $\mathrm{Y}$ & $\mathrm{N}$ & $\begin{array}{l}\text { ICV } \\
\text { cannulations }\end{array}$ & Brain tissue & $\begin{array}{l}\text { Histopathology; } \\
\text { immunohistochemistry; mRNA } \\
\text { and cDNA (RT-PCR), positive } \\
\text { colonies were confirmed by } \\
\text { DNA sequencing, Western- } \\
\text { blotting of the intestines and } \\
\text { retroperitoneal adipose tissue. }\end{array}$ \\
\hline \multicolumn{13}{|c|}{ 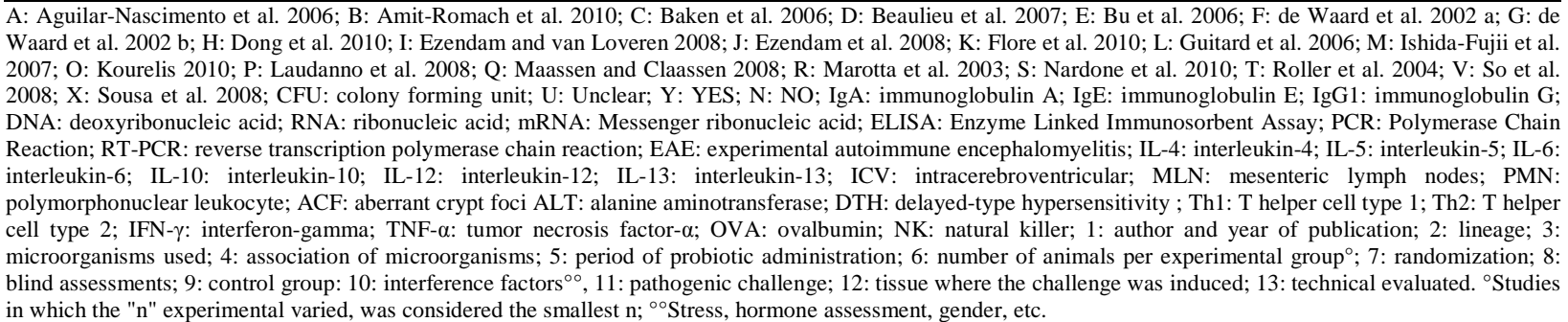 } \\
\hline
\end{tabular}

Table 2 - Evaluation criteria and scores for the selected articles.

\begin{tabular}{|c|c|c|c|c|c|c|c|}
\hline Author & $\begin{array}{l}\text { Mean number of } \\
\text { animals per group }\end{array}$ & $\begin{array}{l}\text { Type of } \\
\text { assay }\end{array}$ & $\begin{array}{l}\text { Control } \\
\text { group }^{* * *}\end{array}$ & $\begin{array}{c}\text { Blind } \\
\text { assessmentd }^{+}\end{array}$ & $\begin{array}{c}\text { Interference } \\
\text { fators }^{++}\end{array}$ & $\begin{array}{l}\text { Pathogenic } \\
\text { challenge }^{++}\end{array}$ & Total \\
\hline $\begin{array}{l}\text { Ezendam and van } \\
\text { Loveren } 2008\end{array}$ & 2 & 2 & 2 & 1 & 2 & 2 & 11 \\
\hline Ezendam et al. 2008 & 2 & 2 & 2 & 1 & 2 & 2 & 11 \\
\hline Laudanno et al. 2008 & 2 & 2 & 2 & 1 & 2 & 2 & 11 \\
\hline So et al. 2008 & 1 & 2 & 2 & 2 & 2 & 2 & 11 \\
\hline $\begin{array}{l}\text { Aguilar-Nascimento } \\
\text { et al. } 2006\end{array}$ & 2 & 2 & 2 & 1 & 1 & 2 & 10 \\
\hline $\begin{array}{l}\text { Amit-Romach } \\
\text { et al. } 2010\end{array}$ & 2 & 2 & 2 & 1 & 1 & 2 & 10 \\
\hline Baken et al. 2006 & 2 & 2 & 2 & 1 & 1 & 2 & 10 \\
\hline Flore et al. 2010 & 2 & 2 & 2 & 1 & 1 & 2 & 10 \\
\hline Bu et al. 2006 & 2 & 2 & 2 & 1 & 1 & 2 & 10 \\
\hline Ishida-Fujii et al. 2007 & 2 & 2 & 2 & 1 & 1 & 2 & 10 \\
\hline Roller et al. 2004 & 2 & 2 & 2 & 1 & 1 & 2 & 10 \\
\hline de Waard et al. 2002a & 2 & 2 & 2 & 1 & 1 & 2 & 10 \\
\hline Beaulieu et al. 2007 & 2 & 1 & 2 & 1 & 2 & 1 & 9 \\
\hline Marotta et al. 2003 & 1 & 2 & 2 & 1 & 1 & 2 & 9 \\
\hline Nardone et al. 2010 & 2 & 1 & 2 & 1 & 1 & 2 & 9 \\
\hline Sousa et al. 2008 & 2 & 1 & 2 & 1 & 1 & 2 & 9 \\
\hline de Waard et al. 2002b & 1 & 2 & 2 & 1 & 1 & 2 & 9 \\
\hline Kourelis 2010 & 1 & 1 & 2 & 1 & 1 & 2 & 8 \\
\hline Guitard et al. 2006 & 1 & 1 & 2 & 1 & 1 & 2 & 8 \\
\hline $\begin{array}{l}\text { Maassen and Claassen } \\
2008\end{array}$ & 1 & 1 & 2 & 1 & 1 & 2 & 8 \\
\hline Dong et al. 2010 & 2 & 1 & 2 & 1 & 1 & 1 & 8 \\
\hline
\end{tabular}

${ }^{*}$ Scores for the sample number were 1 (less than 6 animals/group) and 2 (6 or more animals/group)

*** Nonrandomized experiments or when randomization was not described clearly in the text (score 1) and randomized experiments (score 2)

${ }^{* * *}$ Studies without control groups or those which did not clearly mention a control group in the text (score 1) and studies with a control group (score 2 )

${ }^{+}$Experiments without blind assessments or those in which blind assessments were not clearly reported in the text (score 1) and experiments with blind assessments (score 2)

${ }^{++}$Studies that did not evaluate interference factors (score 1) and studies which evaluated additional factors such as: stress, hormonal evaluation, variations between males and females (score 2)

${ }^{+++}$Studies in which animals were not subjected to experimental challenge (score 1), and studies in which animals were subjected to an experimental challenge (score 2). 


\section{RESULTS}

An initial search of the PubMed database retrieved 24 articles. Of these, three were excluded because were conducted in humans or mice; one evaluated the isolated action of prebiotics; three others were also excluded because they were literature reviews. Thus, of the initial 24 articles retrieved, 18 were selected for this study.

A search of the ISI Web of Science database also retrieved 24 articles, eight of which were duplicates of articles retrieved from PubMed. Of the 16 remaining articles, five were excluded because they were studies on humans, sows and piglets, prebiotics, or were performed in vitro; two others were excluded because they did not evaluate probiotics, and six more were excluded because they were literature reviews. Therefore, three additional papers were selected from this search. A search of the database Scielo did not identify additional articles. Thus, in total 21 articles met the inclusion and exclusion criteria, and were selected for this review. Table 1 presents a summary of the selected studies.

The following rat lineages were used in the studies included in this review: Wistar, Lewis, Sprague Dawley and Fischer. The combinations of two distinct lineages of rats were also used, as well as the combinations of rats with Balb-C mice. In three studies, the authors did not report the rat lineages used.

Bacteria from the genus Lactobacillus were the most commonly used microorganisms in the selected studies, and were reported in $57 \%$ of the papers. The second most common genus was Bifidobacterium (B. animalis and B. longum). The combinations of microorganisms were used in $38 \%$ of the papers, such as Lactobacillus helveticus + Streptococcus thermophilus or Streptococcus thermophilus + Lactobacillus acidophilus + Bifidobacterium lactis, among others.

In $48 \%$ of the articles, probiotics were administered in the feeding, while in $38 \%$ of the studies, probiotics were administered by gavage. Other forms of administration, such as water or castor oil were also mentioned. There was a large variability in the amount of colony forming units (CFU) used among the surveys, and no consensus technique emerged, even among the studies dealing with the same species of bacilli. The duration of probiotic administration (e.g. before, during or after experimental challenge) also varied considerably: probiotics were administered both before and after the challenge in $33 \%$ of the studies; only during the challenge in 14\%; and only after the challenge in 19\%. In $19 \%$ of the studies, probiotics were administered throughout the study period, independent of the timing of the experimental challenge. Other studies administered probiotics only a few days before the animals were killed, in the pre- and post-operatory period.

Of the 21 selected articles, only one reported having conducted a blind evaluation (So et al. 2008), while 16 articles reported randomization of the sample. The number of animals per group ranged from 1 to 32, although three papers did not report the number of animals used per experimental group.

A total of $90 \%$ of the articles induced a pathogenic challenge: $38 \%$ introduced an intestinal challenge (e.g. colitis or tumors, among others); 9.5\% introduced encephalomyelitis; $9.5 \%$ induced liver injury; $4.8 \%$ induced respiratory allergies; $4.8 \%$ induced arthritis; $4.8 \%$ challenged the animals with Escherichia coli; $4.8 \%$ induced ischemia and infusion; $4.8 \%$ induced intracerebroventricular cannulation; and $4.8 \%$ were challenged by the introduction of air pockets into the back of the animals. In $4.8 \%$ of the papers, both encephalomyelitis and respiratory allergy were induced simultaneously (Ezendam et al. 2008).

With respect to the interference factors $24 \%$ of the articles separated male and female groups, while $5 \%$ used the models of stress. However, the vast majority ( $71 \%$ of the articles) did not report any interference factor. In the work of Laudanno et al. (2008), both the sexes (male/female) and stress were evaluated. All the studies used control groups.

\section{DISCUSSION}

Literature reviews are useful to the scientific community in general, and can provide significant insight into a particular research field, since they enable a more complete view of current results. In addition, they can suggest the best protocols to be employed and/or future directions for research (Snodgrass 2006). The present literature review on the efficacy of probiotics at improving the immune response in rats focused on targeting which therapeutic protocols were associated with the best (or more promising) results in this species, and 
could be used as a guide to future studies attempting to reproduce these experiments in other species.

Research using animal models are important, especially given the limitations of investigating certain diseases directly in humans, which often involves the ethical issues and/or risks related to the disease under study. Diseases which can be induced in animal models have the potential to reveal the pathological mechanisms that can be extrapolated to humans, increasing the understanding of human disease. Thus, the use of animal models can help overcoming numerous research limitations and often provides causal relationships more quickly. For these reasons, experimentation on animal systems often represents the first step in many research projects (Taha and Fagundes 2004; DaMatta 2010).

According to Nomoto (2005), excessive use of the antibiotics can induce an imbalance in the intestinal microbiota, encouraging the emergence of antibiotic-resistant bacterial infections, and, at the same time, reducing the possible activation of the immune system prior to infection. Because of this problem, interest in the use of probiotics as a complement to antibiotics has been growing.

Although it is known that probiotics have different properties and functions, the mechanisms by which individual probiotics act in a host are not fully understood. As described in the literature, probiotics are assumed to act via several mechanisms, including: a) competitive exclusion, where probiotics compete with the pathogens for fixation sites and nutrients, thereby temporarily preventing the pathogenic action; b) production of antimicrobial substances, such as bacteriocins, hydrogen peroxide and volatile organic acids; c) induction of direct changes in the immune response, through immune stimulation of residing cells in the enteric tract, which then initiate activation of macrophages, increasing phagocytosis; and d) modulation of enzyme activity by changing the microbial metabolism (Audisio et al. 2000; de Vrese et al. 2001; Ogawa et al. 2001; Cross 2002; Puupponen-Pimia et al. 2002; Hamilton-Miller 2004; Boirivant and Strober 2007; Gillor et al. 2008; Borchers et al. 2009; Ng et al. 2009; Rijkers et al. 2010; Yan and Polk 2010).

Of the 21 articles selected, $86 \%$ reported the beneficial effects from the administration of probiotics on the immune response in rats. Two studies, one conducted by Baken et al. (2006) and one by Guitard et al. (2006) reported unsatisfactory results from the use of probiotics, suggesting that further studies were necessary. Baken et al. (2006) induced autoimmune encephalomyelitis, the same challenge experiment used by Maassen et al. (2008), who concluded that probiotics could suppress this disease. Ezendam et al. (2008) observed a significant reduction in the duration of clinical symptoms, and an improvement in weight gain versus the control group. Guitard et al. (2006) investigated the effect of probiotic administration on the development and progression of an experimental parasite infection (cryptosporidiosis) in lactating rats. Although the rats administered probiotics tended to display faster parasite clearance than the controls, no significant effect was observed in terms of weight gain, parasite burden, mucosal damage or cytokine kinetics in the mucosa during the course of the infection. Overall, these authors found that daily administration of probiotic mixtures containing Lactobacillus casei was not able to eradicate the parasite in their experimental model. However, differences in probiotic strains and dosages could justify the discrepancies between these studies.

The animals underwent intestinal challenge in $48 \%$ of the assessed studies, and all responded positively to the use of probiotics, with the exception of Guitard et al. (2006). The immunostimulant effect associated with probiotic administration could be related to the ability of these microorganisms to interact with Payer's patches and intestinal epithelial cells, thereby activating the mucosal immunity by stimulating the plasma cells, IgA secretion and migration of intestinal T cells (Park et al. 2002; de Vrese et al. 2005).

Of the articles investigating induced respiratory allergies ( $\mathrm{n}=4$ articles), only two reported a positive response. However, probiotics were found to increase the phagocytic activity of alveolar macrophages, suggesting that they could act systemically by inducing the secretion of mediators which could then stimulate the adaptive immune system (Cross 2002).

Significant differences were observed with respect to the doses of probiotics used. However, no differences in results were noted between the highest (Beaulieu et al. 2007) and lowest administered doses (Aguilar-Nascimento et al. 2006): both showed positive immune responses. The immune response to the use of probiotics was 
also not dependent on the time of administration: positive responses were noted when probiotics were administered before pathogen challenge, during the challenge, or both before and after the challenge.

However, no trend was found among the studies analyzed regarding the type of microorganism used for the treatment, preventing the establishment of a general protocol. Lactobacillus were used against several different types of pathogenic challenges, including encephalomyelitis (Baken et al. 2006; Maassen and Claassen 2008); colitis (Amit-Romach et al. 2010); laparotomy with colon anastomosis (Aguilar-Nascimento et al. 2006); and E. coli infection (Ishida-Fujii et al. 2007), among others. With the exception of Baken et al. (2006), all of these articles reported satisfactory results associated with the probiotic administration. However, numerous other microorganisms were also used in the analyzed studies, both alone and in combination. This variation probably stemmed from the fact that the objective of the research was to generally stimulate the immune response of the animals, not to evaluate the specific infections. No relationship was identified between the type of probiotic, pathogenic challenge and the effectiveness of probiotic administration.

Only one of the papers analyzed was conducted by blind assessment. However, $71 \%$ of the articles included a randomized experimental design (the remaining $29 \%$ did not clearly state if the study was randomized or not). Use of blind assessments and randomized evaluations improved the reliability of scientific works, by preventing study investigators from knowing which treatment was administered and in the case of randomized trials, distribution was done randomly (Snodgrass 2006; Taylor and Yildirim 2011).

\section{CONCLUSION}

In the studies assessed in this review, the administration of probiotics has been shown to be associated with a positive induction of the immune response in the presence of a wide range of experimental pathogenic challenges. Therefore, further studies should be encouraged in this field in order to develop new protocols with respect to the microorganism type, dosage and the timing of probiotic administration for specific illnesses.

\section{ACKNOWLEDGEMENTS}

This work was supported in part by FAPEMIG, CNPq, CAPES and the Postgraduate Program in Veterinary Sciences of the Federal University of Lavras, Brazil.

\section{REFERENCES}

Aguilar-Nascimento JE, Prado S, Zafanni G, Salomão AB, Neves JS, Dock-Nascimento DB, et al. Perioperative administration of probiotics: effects on immune response, anastomotic resistance and colonic mucosal trophism. Acta Cir. Bras. 2006; 21: 80-83.

Amit-Romach E, Uni Z, Reifen R. Multistep mechanism of probiotic bacterium, the effect on innate immune system. Mol Nutr Food Res. 2010; 54: 277-284.

Audisio MC, Oliver G, Apella MC. Protective effect of Enterococcus faecium J96, a potential probiotic strain, on chicks infected with Salmonella pullorum. J. Food. Prot. 2000; 63: 1333-1337.

Baken KA, Ezendam J, Gremmer ER, de Klerk A, Pennings JL, Matthee B, et al. Evaluation of immunomodulation by Lactobacillus casei Shirota: immune function, autoimmunity and gene expression. Int J Food Microbiol. 2006; 112: 8-18.

Baptista AS, Horii J, Piedade SMS. Cells of yeasts adhered in corn grains and the storage perspective for use as probiotic. Braz. arch. biol. Technol. 2005; 48: 251-257.

Beaulieu J, Dubuc R, Beaudet N, Dupont C, Lemieux P. Immunomodulation by a malleable matrix composed of fermented whey proteins and lactic acid bacteria. J Med Food. 2007; 10: 67-72.

Bloise E, Torricelli M, Novembri R, Borges LE, Carrarelli P, Reis FM, et al. Heat-killed Lactobacillus rhamnosus GG modulates urocortin and cytokine release in primary trophoblast cells. Placenta. 2010; 31: 867-872.

Boirivant M, Strober W. The mechanism of action of probiotics. Curr Opin Gastroenterol. 2007; 23: 679692.

Borchers AT, Selmi C, Meyers FJ, Keen CL, Gershwin ME. Probiotics and immunity. J Gastroenterol. 2009; 44: 26-46.

Brizuela MA, Serrano P, Pérez Y. Studies on probiotics properties of two lactobacillus strains. Braz. arch. biol. technol. 2001; 44: 95-99.

Bu HF, Wang X, Zhu YQ, Williams RY, Hsueh W, Zheng $\mathrm{X}$, et al. Lysozyme-Modified Probiotic Components Protect Rats against Polymicrobial Sepsis: Role of Macrophages and CathelicidinRelated Innate Immunity. J Immunol. 2006; 177: 8767-8776. 
Budiño FEL, Thomaz MC, Kronka RN, Nakaghi LSO, Tucci FM, Fraga AL, et al. Effect of probiotic and prebiotic inclusion in weaned piglet diets on structure and ultra-structure of small intestine. Braz. arch. biol. technol. 2005; 48: 921-929.

Chaucheyras-Durand F, Walker ND, Bach A. Effects of active dry yeasts on the rumen microbial ecosystem: past, present and future. Anim. Feed Sci. Technol. 2008; 145: 5-26.

Chaucheyras-Durand F. Durant H. Probiotics in animal nutrition and health. Beneficial Microbes. 2010; 1: 39.

Corr SC, Gahan CG, Hill C. Impact of selected Lactobacillus and Bifidobacterium species on Listeria monocytogenes infection and the mucosal immune response. FEMS Immunol Med Microbiol. 2007; 50: 380-388.

Cross ML. Microbes versus microbes: immune signals generated by probiotic lactobacilli and their role in protection against microbial pathogens. FEMS Immunol Med Microbiol. 2002; 34: 245-253.

DaMatta RA. Animal models in biomedical research. Scientia Medica. 2010; 20: 210-211.

de Roock S, van Elk M, van Dijk ME, Timmerman HM, Rijkers GT, Prakken BJ, et al. Lactic acid bacteria differ in their ability to induce functional regulatory T cells in humans. Clin Exp Allergy. 2010; 40: 103-110.

de Vrese M, Stegelmann A, Richter B, Fenselau S, Laue C, Schresenmeir J. Probiotics-compensation for lactase insufficiency. Am J Clin Nutr. 2001; 73: 421S-429S.

de Vrese M, Rautenberg P, Laue C, Koopmans M, Herremans T, Schrezenmeir J. Probiotic bacteria stimulate virus-specific neutralizing antibodies following a booster polio vaccination. Eur J Nutr. 2005; 44: 406-413.

de Waard R, Garssen J, Bokken GC, Vos JG. Antagonistic activity of Lactobacillus casei strain Shirota against gastrointestinal Listeria monocytogenes infection in rats. Int $J$ Food Microbiol. 2002a; 73: 93-100.

de Waard R, Garssen J, Vos JG, Claassen E. Modulation of delayed-type hypersensitivity and acquired cellular resistance by orally administered viable indigenous lactobacilli in Listeria monocytogenes infected Wistar rats. Lett Appl Microbiol. 2002b; 35: 256-260.

Dong P, Yang Y, Wang WP. The role of intestinal bifidobacteria on immune system development in young rats. Early Hum Dev. 2010; 86: 51-58.

Ezendam J, van Loveren $\mathrm{H}$. Lactobacillus casei Shirota administered during lactation increases the duration of autoimmunity in rats and enhances lung inflammation in mice. Br J Nutr. 2008; 99: 83-90.

Ezendam J, de Klerk A, Gremmer ER, van Loveren H Effects of Bifidobacterium animalis administered during lactation on allergic and autoimmune responses in rodents. Clin Exp Immunol. 2008; 154: 424-431.

Fagundes DJ, Taha MO. Animal disease model: choice's criteria and current animals specimens. Acta Cir Bras. 2004; 19: 59-65.

Fink LN. Induction of regulatory $\mathrm{T}$ cells by probiotics: potential for treatment of allergy?. Clin Exp Allergy. 2010; 40: 5-8.

Flore TNE, François ZN, Felicite TM. Immune system stimulation in rats by Lactobacillus sp. isolates from Raffia wine (Raphia vinifera). Cell Immunol. 2010; 260: 63-65.

Food and Health Agricultural Organization of the United Nations - FAO; World Health Organization. Guidelines for the evaluation of probiotics in food. 2002.

Generoso SV, Viana M, Santos R, Martins FS, Machado JAN, Arantes RME, et al. Saccharomyces cerevisiae strain UFMG 905 protects against bacterial translocation, preserves gut barrier integrity and stimulates the immune system in a murine intestinal obstruction model. Arch Microbiol. 2010; 192: 477484.

Gillor O, Etzion A, Riley MA. The dual role of bacteriocins as anti- and probiotics. Appl Microbiol Biotechnol. 2008; 81: 591-606.

Guitard J, Menotti J, Desveaux A, Alimardani P, Porcher R, Derouin F, et al. Experimental study of the effects of probiotics on Cryptosporidium parvum infection in neonatal rats. Parasitol Res. 2006; 99: 522-527.

Hamilton-Miller JMT. Probiotics and prebiotics in the elderly. Postgrad Med J. 2004; 80: 447-451.

Ishida-Fujii K, Sato R, Goto S, Yang X, Kuboki H, Hirano S, et al. Prevention of pathogenic Escherichia coli infection in mice and stimulation of macrophage activation in rats by an oral administration of probiotic Lactobacillus casei I-5. Biosci Biotechnol Biochem. 2007; 71: 866-873.

Kourelis A, Zinonos I, Kakagianni M, Christidou A, Christoglou N, Yiannaki E, et al. Validation of the dorsal air pouch model to predict and examine immunostimulatory responses in the gut. $J$ Appl Microbiol. 2010; 108: 274-284.

Laudanno OM, Cesolari JA, Godoy A, Sutich E, Sarangone S, Catalano J, et al. Bioflora probiotic in immunomodulation and prophylaxis of intestinal bacterial translocation in rats. Dig Dis Sci. 2008; 53: 2667-2670.

Lomax AR, Calder PC. Prebiotics, immune function, infection and inflammation: a review of the evidence. Br J Nutr. 2009; 101: 633-658.

Maassen CB, Claassen E. Strain-dependent effects of probiotic lactobacilli on EAE autoimmunity. Vaccine. 2008; 26: 2056-2057.

Maragkoudakis PA, Mountzouris KC, Rosu C, Zoumpopoulou G, Papadimitriou K, Dalaka E, et al. Feed supplementation of Lactobacillus plantarum 
PCA 236 modulates gut microbiota and milk fatty acid composition in dairy goats: a preliminary study. Int J Food Microbiol. 2010; 141: S109-S116.

Marko NF, Weil RJ. The role of observational investigations in comparative effectiveness research; Value in Health. 2010; 13: 989-997.

Marotta F, Naito Y, Minelli E, Tajiri H, Bertuccelli J, $\mathrm{Wu} \mathrm{CC}$, et al. Chemopreventive effect of a probiotic preparation on the development of preneoplastic and neoplastic colonic lesions: an experimental study. Hepatogastroenterolog. 2003; 50: 1914-1918.

Mountzouris KC, Balaskas C, Xanthakos I, Tzivinikou A, Fegeros K. Effects of a multi-species probiotic on biomarkers of competitive exclusion efficacy in broilers challenged with Salmonella enteritidis. $\mathrm{Br}$ Poult Sci. 2009; 50: 467-478.

Nardone G, Compare D, Ligouri E, di Mauro V, Rocco A, Barone M, et al. Protective effects of Lactobacillus paracasei $\mathrm{f19}$ in a rat model of oxidative and metabolic hepatic injury. Am J Physiol Gastrointest Liver Physiol. 2010; 299: 669-676.

Negre A, Bensignor E, Guillot J. Evidence-based veterinary dermatology: a systematic review of interventions for Malassezia dermatitis in dogs. Vet Dermatol. 2009; 1: 1-12.

Ng SC, Hart AL, Kamm MA, Stagg AJ, Knight SC. Mechanisms of action of probiotics: recent advances. Inflamm Bowel Dis. 2009; 15: 300-310.

Noli C, Auxilia ST. Treatment of canine old world visceral leishmaniasis: a systematic review. Vet Dermatol. 2005; 16: 213-232.

Nomoto K. Prevention of infections by probiotics. $J$ Biosci Bioeng. 2005; 100: 583-592.

Ogawa M, Shimizu K, Nomoto K, Tanaka R, Hambata $\mathrm{T}$, Yamasaki S, et al. Inhibition of in vitro growth of Shiga toxin producing Escherichia coli O157:H7 by probiotic Lactobacillus strains due to production of lactic acid. Int J Food Microbiol. 2001; 68: 135-140.

Park JH, Um JI, Lee BJ, Goh JS, Park SY, Kim WS, et al. Encapsulated Bifidobacterium bifidum potentiates intestinal IgA production. Cell Immunol. 2002; 219: 22-27.

Peran L, Camuesco D, Comalada D, Bailon E, Henriksson A, Xaus J, et al. A comparative study of the preventative effects exerted by three probiotics, Bifidobacterium lactis, Lactobacillus casei and Lactobacillus acidophilus, in the TNBS model of rat colitis. J Appl Microbiol. 2007; 103: 836-844.

Pereira UP, Oliveira DG, Mesquita LR, Costa GM, Pereira LJ. Efficacy of Staphylococcus aureus vaccines for bovine mastitis: A systematic review. Vet Microbiol. 2011; 148: 117-124.

Puupponen-Pimia R, Aura AM, Oksman-Caldentey KM, Myllarinen P, Saarela M, Mattila-Sandholm T, et al. Development of functional ingredients for gut health. Trends Food Sci Tech. 2002; 13: 3-11.

Rijkers GT, Bengmark S, Enck P, Haller D, Herz U, Kalliomaki M, et al. Guidance for substantiating the evidence for beneficial effects of probiotics: current status and recommendations for future research. $J$ Nutr. 2010; 140: 671S-676S.

Roller M, Rechkemmer G, Watzl B. Prebiotic inulin enriched with oligofructose in combination with the probiotics Lactobacillus rhamnosus and Bifidobacterium lactis modulates intestinal immune functions in rats. J Nutr. 2004; 134: 153-156.

Salminen SJ, Gueimonde M, Isolauri E. Probiotics that modify disease risk. J Nutr. 2005; 135: 1294-1298.

Siró I, Kápolna E, Kápolna B, Lugasi A. Functional food. Product development, marketing and consumer acceptance - A review. Appetite. 2008; 51: 456-467.

Snodgrass R. Single- versus double-blind reviewing: an analysis of the literature. Sigmod Rec. 2006; 35: 8-21.

So JS, Kwon HK, Lee CG, Yi HJ, Park JA, Lim SY, et al. Lactobacillus casei suppresses experimental arthritis by down-regulating $\mathrm{T}$ helper 1 effector functions. Mol Immunol. 2008; 45: 2690-2699.

Sousa R, Halper J, Zhang J, Lewis SJ, Li WO. Effect of Lactobacillus acidophilus supernatants on body weight and leptin expression is rats. BMC Complement Altern Med. 2008; 8: 5.

Taylor CR, Yildirim H. Subjective performance and the value of blind evaluation. Review of Economic Studies. 2011; 78: 762-794.

Tsubura S, Mizunuma H, Ishikawa S, Oyake I, Okabayashi M, Katoh K, et al. The effect of Baccilus subtilis mouth rinsing in patients with periodontitis. Eur J Clin Microbiol Infect Dis. 2009; 28: 13531356.

Vanderpool C, Yan F, Polk DB. Mechanisms of probiotic action: implications for therapeutic applications in inflammatory bowel diseases. Inflamm Bowel Dis. 2008; 14: 1585-1596.

Verdenelli MC, Ghelfi F, Silvi S, Orpianesi C, Cecchini C, Cresci A. Probiotic properties of Lactobacillus rhamnosus and Lactobacillus paracasei isolated from human faeces. Eur J Nutr. 2009; 48: 355-363.

Yan F, Polk DB. Probiotics: progress toward novel therapies for intestinal diseases. Curr Opin Gastroenterol. 2010; 26: 95-101.

Zanini K, Marzotto M, Castellazi A, Borsari A, Dellaglio F, Torriani $\mathrm{S}$. The effects of fermented milks with simple and complex probiotic mixtures on the intestine microbiota and immune response of healthy adults and children. Int Dairy J. 2007; 17: 1332-1343.

Zeng XQ, Pan DD, Guo YX. The probiotic properties of Lactobacillus buchneri P2. J Appl Microbiol. 2010; 108: 2059-2066.

Received: August 25, 2011; Revised: December 29, 2011; Accepted: March 20, 2012. 